\title{
Protein/peptide purification by three-well OFFGEL electrophoresis with immobilized ultra narrow $\mathrm{pH}$ gradient gels $\uparrow$
}

\author{
Elena Tobolkina, Fernando Cortés-Salazar, Liang Qiao and Hubert H. Girault* \\ Purification and desalting of protein and peptide samples by three-well OFFGEL electrophoresis with \\ immobilized ultra narrow $\mathrm{pH}$ gradient gels is proposed as a fast preparative strategy for proteomics. The \\ gist of this strategy is to separate proteins and peptides according to their isoelectric points and to \\ isolate those of a given $\mathrm{pl}$ value equal to the mean $\mathrm{pH}$ value of the gel. The present approach has been \\ demonstrated both on protein mixtures and a digested Escherichia coli protein extract. UV-Vis \\ spectroscopy, MALDI-MS, SDS-PAGE and LC-MS/MS were employed for the quantitative and qualitative \\ characterization of the separation results. The electrophoretic methodology has been simulated by finite \\ element methods.
}

Received 9th January 2014 Accepted 7th April 2014

DOI: 10.1039/c4ay00088a

www.rsc.org/methods the gel is placed under an array of wells that are filled with sample solutions. Proteins or peptides are fractionated according to their isoelectric points, while the separated components are directly recovered in liquid fractions on top of the gel and thus easily analyzed by other techniques such as LC-MS. ${ }^{12-14}$ In addition to being a high-resolution separation technique, IEF electrophoresis also provides information on the sample isoelectric point that is valuable for identification. For instance, it has been suggested that a confident identification of peptides can be obtained by employing the information of both molecular weight from MS and pI from IEF even without tandem MS. ${ }^{15}$

Considering the complexity of proteomic samples, new simple strategies and methods are still needed to pre-fractionate, separate, detect and identify the relevant species ${ }^{\mathbf{1 6}}$ even if many techniques for preparative purposes, e.g. fractionation, simplification and purification of tissue extracts, have already been developed. ${ }^{17-20}$ The proteomic samples, depending on their nature, may contain a high concentration of salts or detergents, causing a major problem for mass spectrometry analysis. The use of a microchip ${ }^{21}$ and OFFGEL flow cells ${ }^{22}$ was proposed in order to overcome the time-consuming desalting techniques such as dialysis, ${ }^{23}$ gel filtration ${ }^{24}$ or precipitation techniques. ${ }^{25}$ To decrease the experimental time and to improve the protein recovery, a multielectrode setup was introduced recently for OFFGEL electrophoresis. ${ }^{26}$

Herein, we have developed an electrophoretic separation method with an immobilized ultra narrow $\mathrm{pH}$ gradient (UNPG) gel centred on a mean $\mathrm{pH}$ value, which in comparison to the previous OFFGEL reports is used in a miniaturized version as a preparative proteomic technique for fast sample purification and desalting. Proteins/peptides can be separated according to their electrophoretic mobility at the mean $\mathrm{pH}$ value and
Laboratoire d'Electrochimie Physique et Analytique, Ecole Polytechnique Fédérale de Lausanne (EPFL), Station 6, CH-1015 Lausanne, Switzerland. E-mail: hubert. girault@epfl.ch; Fax: +41-21-693-3667; Tel: +41-21-693-3145

$\dagger$ Electronic supplementary information (ESI) available. See DOI: 10.1039/c4ay00088a 
fractionated according to their charge at this $\mathrm{pH}$. Immobilized UNPG gels can be obtained similarly to IPG gels by polymerization of acidic or basic monomers (Immobilines) in different ratios or simply obtained by cutting an area with a defined $\mathrm{pH}$ value from a commercially available IPG plate gel.

Using UNPG gels, ampholytes were rapidly fractionated by a three-well OFFGEL device into 3 fractions: the cathodic one containing proteins or peptides having a pI larger than the mean $\mathrm{pH}$ value of the gel in the reservoir near the cathode, the anodic one for species with a pI smaller than the mean $\mathrm{pH}$ of the gel near the anode, and a third one in the middle reservoir for species that have a pI within the narrow $\mathrm{pH}$ range. This concept was first demonstrated by separating a mixture of four proteins followed by protein identification by matrix-assisted laser desorption/ionization mass spectrometry (MALDI-MS). The protein recovery was measured by UV-Vis spectroscopy. Additionally, purification of an Escherichia coli (E. coli) extract was performed, demonstrating that the proposed methodology can be applied to complex samples. Furthermore, an E. coli protein extract was digested and the peptide mixture was first separated in the three-well device and then analysed by LC-MS/ MS analysis. Moreover, it was shown that the three-well device could be used for partial desalting. All the results suggested that electrophoretic separation with UNPG gels provides an efficient strategy for fast purification of protein mixtures, and can thereby be used as a preparative technique for proteomics.

\section{Materials and methods}

\subsection{Materials}

OFFGEL: Immobiline $\rightarrow$ DryPlate, linear $\mathrm{pH}$ range from 4.0 to 7.0, was purchased from Amersham Biosciences (Uppsala, Sweden). Proteins and solutions: $\alpha$-casein (pI 4.6) from bovine milk was from Fluka (Buchs, Switzerland). $\alpha$-Lactalbumin from bovine milk type I (pI 5.02), $\beta$-lactoglobulin A from bovine milk (pI 5.1), myoglobin from horse skeletal muscle (pI 7.0, 7.4) and cytochrome $\mathrm{C}$ from horse heart (pI 9.6) as well as sinapinic acid, acetonitrile, trifluoroacetic acid, methanol and acetic acid of the purest grade $(>99.9 \%)$ were obtained from Sigma-Aldrich (Schnelldorf, Switzerland). Deionized (DI) water was purified using an Alpha Q Millipore system (Zug, Switzerland) and used in all aqueous solutions. Digestion and $L C-M S / M S$ : 1,4-dithio-DLthreitol (DTT, >99.5\%), urea and iodoacetamide (IAA) were from Fluka (Buchs, Switzerland). Trypsin from bovine pancreas was from AppliChem (Darmstadt, Germany). SDS: sodium dodecyl sulfate (SDS), Trizma base, bromophenol blue, ammonium persulfate (APS), $N, N, N^{\prime}, N^{\prime}$-tetramethylenediamine (TEMED), acrylamide and bis-acrylamide solution were all from Sigma (Buchs, Switzerland). Silver staining kit for protein visualization was purchased from Amersham Biosciences (Uppsala, Sweden).

\section{$2.2 \quad \mathrm{UV}$-Vis spectroscopy}

The UV-Visible absorption spectra were obtained with a standard spectrophotometer (Perkin Elmer, model Lambda XLS+) using quartz cells with a path length of $1 \mathrm{~cm}$. A calibration bicinchoninic acid (BCA) protein assay kit for determining protein concentrations was obtained from Thermo Scientific (Rockford, USA).

\subsection{Soluble $E$. coli protein extract preparation}

An over-night $200 \mathrm{~mL}$ culture of $E$. coli (strain DH5 $\alpha$ ) was collected by $10 \mathrm{~min}$ centrifugation at $5000 \mathrm{~g}$ and $4{ }^{\circ} \mathrm{C}$. The cell pellet ( $0.6 \mathrm{~g}$ wet weight) was re-suspended in $3 \mathrm{~mL}$ of lysis buffer (50 mM Tris-HCl, pH 7.5, 5 mM EDTA) and cells were disrupted by sonication $(10 \times 10$ pulses of $1 \mathrm{~s}$ at $30 \mathrm{~W})$. Cell debris were removed by $10 \mathrm{~min}$ centrifugation at $2000 \mathrm{~g}$. Ultracentrifugation $\left(1 \mathrm{~h}\right.$ at $100000 \mathrm{~g}$ at $4{ }^{\circ} \mathrm{C}$ ) was applied to the total cell extract to remove membranes and membrane-bound proteins. The supernatant was collected and was considered as the soluble fraction of $E$. coli proteins.

\subsection{Tryptic digestion}

$30 \mu \mathrm{L}$ of urea $(18 \mathrm{M})$ was added to $70 \mu \mathrm{L}$ of $E$. coli protein extract with the initial concentration of $10 \mathrm{mg} \mathrm{mL}^{-1} .5 \mu \mathrm{L}$ of $200 \mathrm{mM}$ DTT in $50 \mathrm{mM}$ Tris- $\mathrm{HCl}$ was added to the extract mixture and incubated for $1 \mathrm{~h}$ at room temperature in the dark. Afterwards, $20 \mu \mathrm{L}$ of $200 \mathrm{mM}$ IAA in $50 \mathrm{mM}$ Tris- $\mathrm{HCl}$ was added and the mixture was incubated for $1 \mathrm{~h}$ at room temperature in the dark. To consume any unreacted iodoacetamide, $20 \mu \mathrm{L}$ of $200 \mathrm{mM}$ DTT in $50 \mathrm{mM}$ Tris-HCl was added. To reduce the urea concentration to $\approx 0.6 \mathrm{M}, 775 \mu \mathrm{L}$ of $50 \mathrm{mM}$ Tris- $\mathrm{HCl}$ solution was added. Finally, the trypsin was added to the solution with a final trypsin : protein ratio of $1: 50(\mathrm{w} / \mathrm{w})$. The digestion was performed at $37^{\circ} \mathrm{C}$ overnight.

\subsection{Electrophoretic purification with immobilized UNPG gels}

A commercial gel plate with a linear $\mathrm{pH}$ range 4-7 (Immobiline DryPlate $\mathrm{pH}=4-7, T=4 \%, C=3 \%$ ) was cut at the desired mean $\mathrm{pH}$ value to obtain gel strips with an ultra narrow $\mathrm{pH}$ gradient of $\approx 0.27 \mathrm{pH}$ units per $\mathrm{cm}$. After re-swelling in water for 1 hour, the strip was inserted in a simple three-well OFFGEL device (see Scheme 1) for separating the ampholytes according to their charge at the chosen $\mathrm{pH}$ and also for sample desalting.

During electrophoresis, Pt electrodes were placed at the outer wells. Each of the wells was filled with $150 \mu \mathrm{L}$ of DI water. The sample was loaded in the middle well and electrophoresis was performed with a high voltage power supply of Pharmacia Biotech EPS 3500 XL (Sweden). It is very important to keep the sample in a concentration range equal to 1-10 mg per component per $\mathrm{cm}$ of gel in order to avoid overloading of the sample and possible electroosmotic flow. ${ }^{9}$ The purification was performed either with $10 \mu \mathrm{L}$ of a protein mixture, containing $\alpha$-casein, $\alpha$-lactalbumin, cytochrome $\mathrm{C}$ and myoglobin $(26 \mu \mathrm{g}$ $\mathrm{mL}^{-1}$ each) or with $30 \mu \mathrm{L}$ of $E$. coli protein or its digest. Threewell OFFGEL electrophoresis in all the cases was performed under the following conditions: $30 \mathrm{~min}$ at $150 \mathrm{~V}$ and then $4-5 \mathrm{~h}$ at $400 \mathrm{~V}$, the current limit was set at $1 \mathrm{~mA}$. After fractionation with the immobilized UNPG gels, soluble fractions were collected from all the wells and further separated by MS analysis or by SDS-PAGE to obtain a two-dimensional map of the proteins present in the $E$. coli extract. SDS-PAGE was always run 
a)

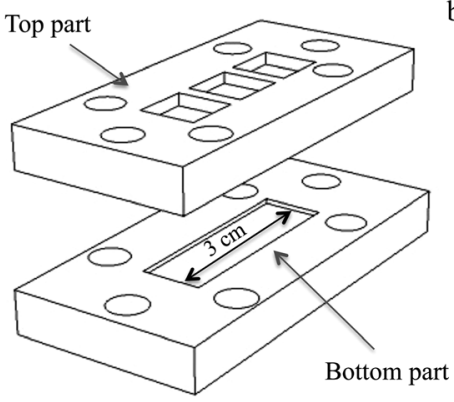

b)

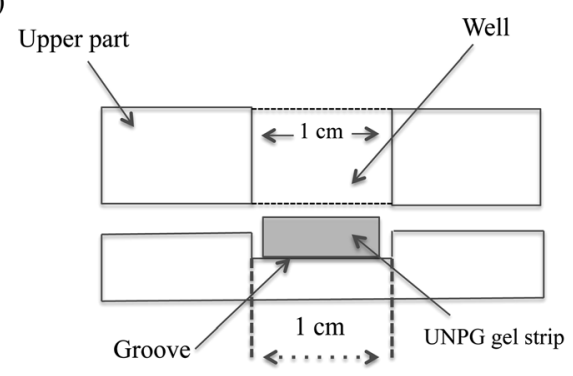

Scheme 1 Schematic representation of (a) the top and bottom view of the three-well device, and (b) cross-section view of the three-well device with an UNPG strip placed in the groove of the bottom part.

for 2 hours with a starting applied potential of $60 \mathrm{~V}$ and $100 \mathrm{~V}$ after 1 hour.

\subsection{MALDI-MS analysis}

The protein analyses were performed on a Microflex LRF MALDI-TOF instrument (Bruker Daltonics, Bremen, Germany) equipped with a $337 \mathrm{~nm}$ nitrogen laser. $1 \mu \mathrm{L}$ of the extracted protein fraction from the three-well device was deposited on a steel target plate to dry under ambient conditions. Afterwards, $1 \mu \mathrm{L}$ of sinapinic acid (SA) matrix ( $15 \mathrm{mg} \mathrm{mL}^{-1}$ sinapinic acid in $50 \%$ acetonitrile, $0.1 \%$ trifluoroacetic acid and $49.9 \%$ water) was added and left to dry at room temperature and pressure.

\subsection{LC-MS/MS analysis}

Liquid chromatography was performed on an ACCELA LC system (ThermoFisher Scientific, Reinach, Switzerland). $20 \mu \mathrm{L}$ of $E$. coli digest was loaded on a C-18 reversed-phase packed column $\left(2.0 \mathrm{~mm}\right.$ ID $\times 150 \mathrm{~mm}$, COSMOSIL, $5 \mathrm{C}_{18}$-MS-II $)$ with a loop loading speed of $8.0 \mu \mathrm{L} \mathrm{s}^{-1}$. The mobile phase consisted of A (ACN/TFA 99.95/0.05 (v/v)) and B (water/TFA 99.95/0.05 (v/v)). The gradient was from 5 to $50 \%$ of solvent $A$ in $66 \mathrm{~min}$, followed by the increase from 50 to $95 \%$ of A in $29 \mathrm{~min}$. The mobile phase flow rate was always $200 \mu \mathrm{L} \min ^{-1}$. Electrospray ionization tandem MS (ESI-MS/MS) analysis was performed on a linear ion trap mass spectrometer of Thermo LTQ Velos (ThermoFisher Scientific, Reinach, Switzerland). MS/MS detection was operated in a positive ion mode with an $\mathrm{m} / \mathrm{z}$ scanning range of 400-2000 and collision induced dissociation. LC-MS/MS data processing was performed with the Trans-Proteomic Pipeline (TPP), which is a set of integrated tools for MS/MS proteomics, developed at the Seattle Proteome Center of the Institute for Systems Biology in the USA (http://tools.proteomecenter.org/ wiki/index.php?title=Software:TPP). The peptide assignment was performed with $\mathrm{X}$ ! Tandem as the search engine and UniProtKB as the database. Results validation was performed with the PeptideProphet of TPP.

\subsection{Finite element simulations}

The simulation of the electrical properties of the three-well device was performed using commercial finite element package COMSOL Multiphysics (version 3.5a) operating under Ubuntu
8.04 environment installed on a four core MacPro with a $2.66 \mathrm{GHz}$ processing unit and $9.8 \mathrm{~Gb}$ of RAM. Details of the geometrical arrangement of the model, mesh, boundary conditions and domain equations are summarized in the generated COMSOL report file (see ESI, SI-1†).

\section{Results and discussion}

\subsection{Principle: electrophoretic separation with immobilized UNPG gels}

The electrophoretic separation/desalting method using a polyacrylamide UNPG gel is based on the electrophoretic mobility difference of charged proteins or peptides loaded in the central well of the device as illustrated in Scheme 2.

Upon application of an electric field, the proteins/peptides migrate in and over the polyacrylamide gel having a defined mean $\mathrm{pH}$ value. The proteins/peptides with $\mathrm{pI}$ higher than the mean $\mathrm{pH}$ of the gel will be positively charged $\left(\mathrm{c}^{+}, \mathrm{d}^{++}\right.$in Scheme 2 ) and therefore will migrate towards the cathode. Additionally, the proteins with larger net charge $\left(\mathrm{d}^{++}\right)$or smaller size will migrate faster than the others allowing a protein fractionation based on mobility. In contrast, the proteins/peptides $\left(\mathrm{a}^{-}\right)$with a pI lower than the mean pH of the gel will be negatively charged and therefore migrate towards the anode. The proteins/peptides (b) with a pI equal or similar to the mean $\mathrm{pH}$ of the gel are globally neutral and then stay in the middle well without significant migration. Concentration gradient and diffusion can happen in the first and the third well but not in the middle well because of isoelectric focusing. In addition to sample fractionation, the UNPG gel electrophoresis can also be used for sample desalting when the target proteins/peptides have a pI close to the mean $\mathrm{pH}$ of the gel, where samples will stay in the middle well and salts will migrate to the cathode or the anode.

An important parameter for this methodology is the migration velocity $\left(V_{\mathrm{m}}\right)$ of the ampholytes determined both by their charge and their electrochemical mobility. $V_{\mathrm{m}}$ is classically defined as (eqn (1)):

$$
V_{\mathrm{m}}=-\frac{z F}{R T} D \nabla \phi=-z F \tilde{u} \nabla \phi=u E
$$

where $z$ is the charge of the ampholyte at the mean $\mathrm{pH}$ value, $F$ is the Faraday constant, $R$ is the gas constant, $T$ is the 
I. Loading and fractionation of sample
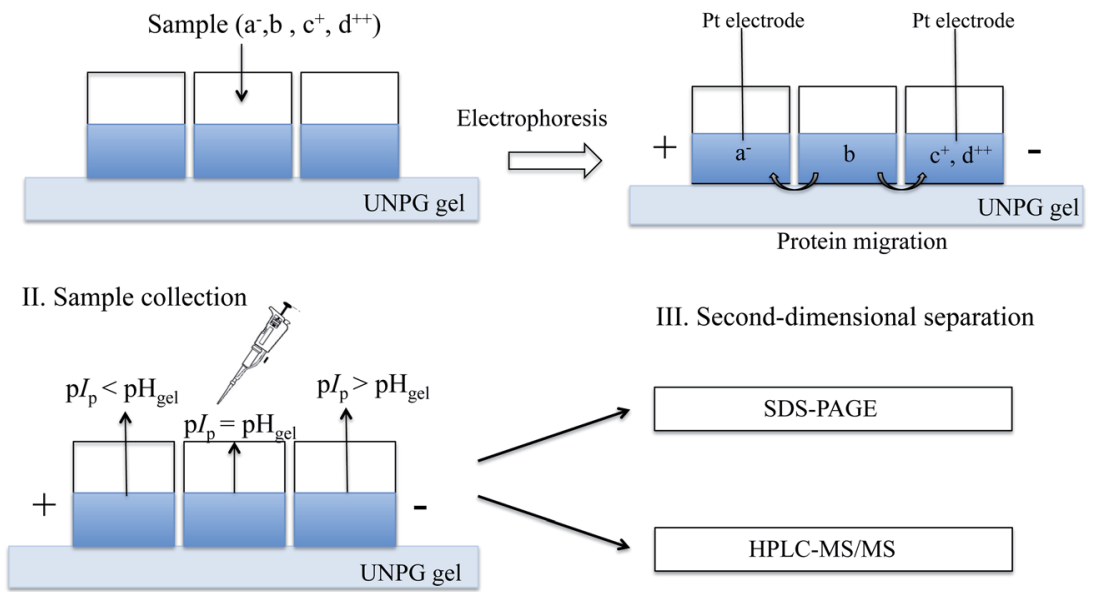

Scheme 2 Schematic representation of an UNPG gel electrophoretic separation method coupled with a second-dimension separation of HPLC-MS/MS or SDS-PAGE. $\mathrm{pH}_{\text {gel }}$ : the mean $\mathrm{pH}$ value of the UNPG gel; $\mathrm{pl}$ : the isoelectric point of proteins or peptides.

temperature, $D$ is the diffusion coefficient of the ampholyte, $\tilde{u}$ is the electrochemical mobility, $u$ is the electrophoretic mobility and $E$ is the applied electric field. ${ }^{27}$

Indeed, the migration of charged species during an electrophoretic separation follows the electric field according to the Nernst-Planck equation. In the present case, the separation is conducted in and above the gel in a three-well configuration. Fig. 1 illustrates the distribution of the electric field $\left(E_{\mathrm{n}}\right)$ demonstrating a significant inhomogeneity, especially near the well edges (see also a cross-section view on $E_{\mathrm{n}}$ distribution in Fig. 1b). Even in the absence of an electrode in the central well where the sample is loaded, the electric field penetrates the liquid medium and further drives charged species into the gel, where the separation occurs according to the $\mathrm{pH}$ of the gel.

\subsection{Purification on UNPG gels}

Protein purification can be realized according to their charge with a very short UNPG gel strip. A mixture of four proteins with different $\mathrm{pI}$ values $(\alpha$-casein $(\mathrm{pI}=4.6), \alpha$-lactalbumin $(\mathrm{pI}=$ 5.02), cytochrome $\mathrm{C}(\mathrm{pI}=9.6)$ and myoglobin $(\mathrm{pI}=7.0), 26 \mu \mathrm{g}$ $\mathrm{mL}^{-1}$ each) was loaded in the middle well and separated on a UNPG gel $(\mathrm{pH}=5-5.27)$. The applied potential difference between the electrodes was $150 \mathrm{~V}$ for $30 \mathrm{~min}$ and then increased up to $300 \mathrm{~V}$ for $3 \mathrm{~h}$, the limiting current was $1 \mathrm{~mA}$. Due to the fact that cytochrome $\mathrm{C}$ and myoglobin are coloured proteins, it was easy to visualize their migration inside the gel. At the end of the separation, the fractions were collected and analysed by MALDI-MS (see Fig. 2). UV-Vis spectroscopy was employed to quantify the amount of proteins collected after fractionation. The results are summarized in Table 1.

According to the MS results shown in Fig. 2 and the UV-Vis quantitative analysis summarized in Table 1 , all the proteins were completely fractionated according to their $\mathrm{pI}$ and reached the expected position (i.e. wells). For instance, $\alpha$-lactalbumin was detected from the middle well, since the $\mathrm{pI}$ of this protein is within the $\mathrm{pH}$ range of the UNPG gel. Cytochrome $\mathrm{C}$ and myoglobin migrated to the third well (cathodic side), due to the fact that they were both positively charged. Similarly, the negatively charged $\alpha$-casein migrated to the first well (anodic side). The protein recovery after separation was analysed by UVVis spectroscopy showing very high recovery in the central well used for purification. The recovery yields in the side wells are less due to the sample loss in the polyacrylamide gel and perhaps due to the reaction occurring on the electrode. As depicted in Fig. 1, the electric field near the well edges is low, which can lead to inefficient protein recovery. In order to increase the protein recovery in wells 1 and 3 a longer experimental time is required.
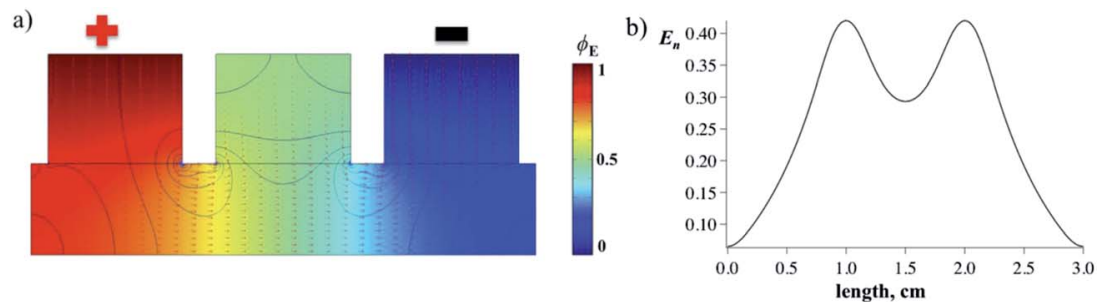

Fig. 1 Simulated electrical properties in a three-well device. (a) The overlay of color map illustrating electric potential distribution ( $\phi_{\mathrm{E}}$ ) and the contour plot depicting the isovalue lines for the electric field $\left(E_{n}\right)$ and $(b)$ the distribution of the electric field along the central cross-section inside the UNPG gel. For simplicity, the electrodes are considered to be at the top surface of the outer reservoirs. 

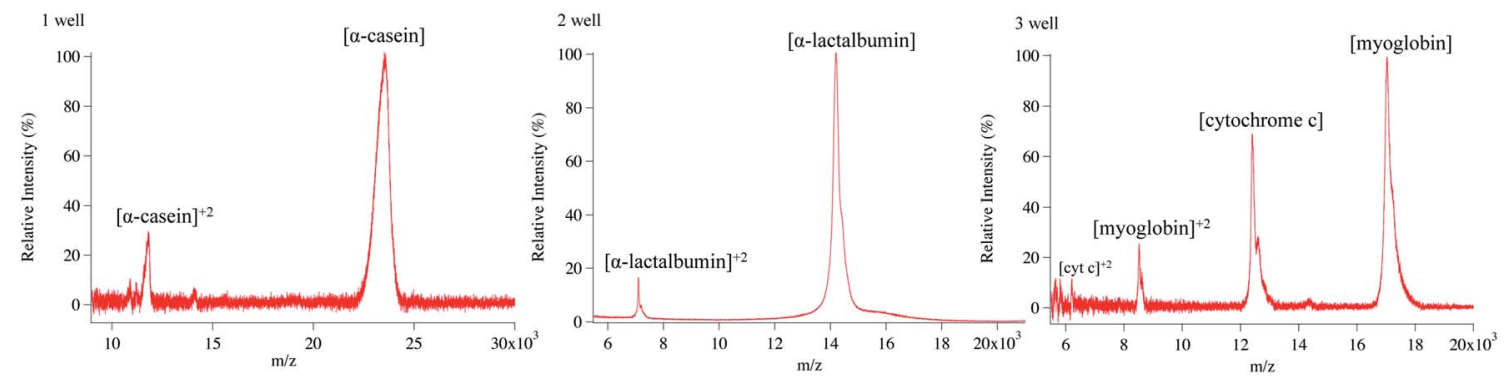

Fig. 2 Mass spectra of the fractions from wells no. 1 (anodic side), 2 (middle well) and 3 (cathodic side) after electrophoresis performed with the three-well device over an UNPG gel $(\mathrm{pH}=5-5.27)$. The samples were analyzed by MALDI-MS with sinapinic acid matrix.

Table 1 Protein recovery determined after electrophoretic separation in the three-well device over an UNPG gel (pH 5-5.27) using UV-spectroscopy

\begin{tabular}{llll}
\hline Well no. & $\begin{array}{l}\text { Identified } \\
\text { proteins }\end{array}$ & $\begin{array}{l}\text { Initial concentration } \\
\text { of the proteins loaded }\end{array}$ & $\begin{array}{l}\text { Amount of protein } \\
\text { recovery }\end{array}$ \\
\hline 1 (anodic side) & $\alpha$-Casein & $26 \mu \mathrm{g} \mathrm{mL}$ & $13 \mu \mathrm{g} \mathrm{mL} \mathrm{mL}^{-1}$ \\
2 (middle) & $\alpha$-Lactalbumin & $26 \mu \mathrm{g} \mathrm{mL}$ & $25 \mu \mathrm{mL}^{-1}$ \\
3 (cathodic side) & Myoglobin, cytochrome C & $52^{a} \mu \mathrm{g} \mathrm{mL} \mathrm{mL}^{-1}$ & $35 \mu \mathrm{g} \mathrm{mL}^{-1}$ \\
${ }^{a}$ This value corresponds to the summed concentration of the two proteins present.
\end{tabular}

This relatively high recovery resulted from the large solution to gel volume ratio; therefore increasing the amount of solution or decreasing the size of gel might lead to even higher protein recoveries. However, an increased solution-to-gel volume ratio can also lead to decreased buffer capacity of the system, and an optimized ratio should be considered for both sample separation and recovery.

\subsection{Sample desalting on UNPG gels}

In addition to separation, protein/peptide samples can also be rapidly and easily desalted using the three-well device on an UNPG gel. A gel strip with a pH gradient in the range of 5-5.27 was introduced into the device and $100 \mu \mathrm{L}$ of DI water was added into each well. $10 \mu \mathrm{L}$ of the solution of $\beta$-lactoglobulin A $\left(1 \mathrm{mg} \mathrm{mL} \mathrm{m}^{-1}, \mathrm{pI}=5.1\right.$ ) containing $1 \mathrm{M} \mathrm{NaCl}$ was loaded into the middle well and the following experimental conditions were employed for the sample desalting: voltage applied $=100 \mathrm{~V}$, limiting current $=1 \mathrm{~mA}$. The $\mathrm{pH}$ of the gel was chosen to fit the requirements of the electrophoretic separation principle (see Section 3.1) that means the proteins with pI equal or similar to the mean $\mathrm{pH}$ of the gel would not migrate from the well where they were loaded. After the electric field was applied along the three-well system, the $\mathrm{Na}^{+}$and $\mathrm{Cl}^{-}$ions penetrated inside the gel and started to migrate to the electrodes with an opposite charge, while the redox reaction happened on the electrodes. In 1 hour the fractions from each well were collected and analysed by MALDI-MS (see Fig. 3). Since no protein was detected in well no. 1 and 3, only the mass spectrum of the middle well containing the $\beta$-lactoglobulin A is shown.

Fig. 3 illustrates the desalting effect of the three-well device using the UNPG gel. Fig. $3 \mathrm{a}$ and $\mathrm{b}$ show the MALDI plate image containing the protein sample with $1 \mathrm{M} \mathrm{NaCl}$ before and after the desalting. As it can be observed that the crystals of the sample after the desalting are smaller in comparison to those observed before desalting, suggesting the removal of $\mathrm{NaCl}$. The desalting effect is also demonstrated in the mass spectra of $\beta$-lactoglobulin A. Fig. 3d presents a much better MS signal for the protein in comparison to the one in Fig. 3c. Indeed, the laser intensity was increased by $20 \%$ to get the mass spectrum in Fig. 3c compared to that in Fig. $3 d$. These results show that the three-well device with an UNPG gel can provide effective and rapid desalting prior to further analysis.

\subsection{Purification of $E$. coli extract on UNPG gels}

To determine the capability of purifying complex samples and to show that the electrophoretic separation with UNPG gels could be used as a fractionation strategy prior to other separation techniques, such as SDS-PAGE, a three-well fractionation of an $E$. coli protein extract spiked with $\alpha$-casein and cytochrome $\mathrm{C}$ was performed using a gel with a $\mathrm{pH}$ gradient of $5-5.27$. The extract from $E$. coli was prepared with a protein concentration of approximately $30 \mu \mathrm{g} \mathrm{mL} \mathrm{m}^{-1}$ and added in each well of the device. The sample was spiked with cytochrome $\mathrm{C}$ and $\alpha$-casein $(3 \mu \mathrm{g}$ $\mathrm{mL}^{-1}$ each) in order to observe the effect of such a complex matrix on the protein fractionation. The fractions collected after fractionation in a three-well device were further separated by SDS-PAGE electrophoresis. The gels were silver stained to visualize the separated proteins (see ESI, SI- $\dagger \dagger$ ). SDS-PAGE of the pure $E$. coli extract presents a high degree of protein band overlapping, which is raised from the complexity of this protein mixture. After the fractionation in a three-well device using the ultra narrow $\mathrm{pH}$ gradient gel, the spiked $\alpha$-casein $(\mathrm{pI}=4.6)$ and 
a)

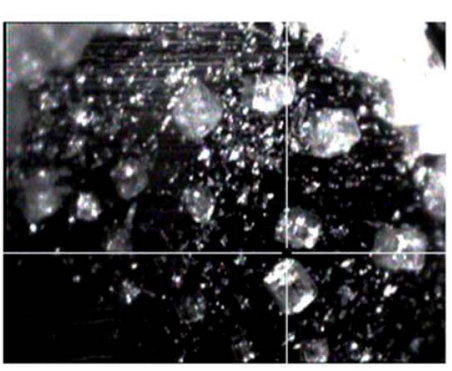

b)

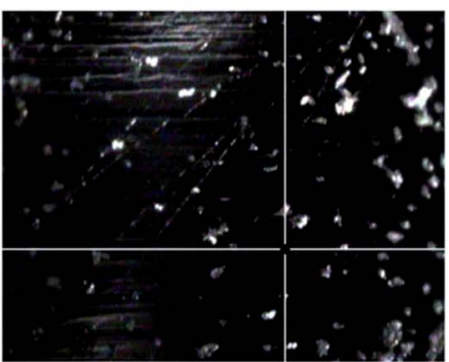

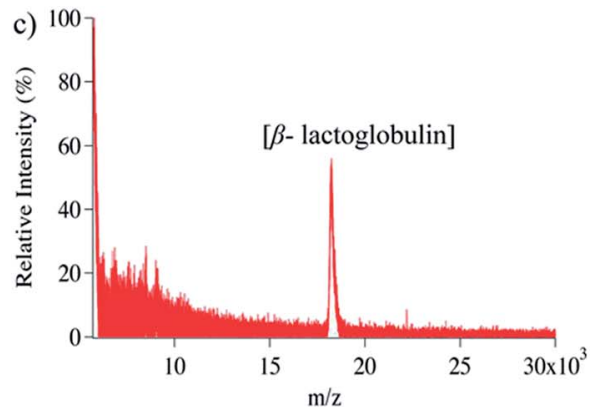

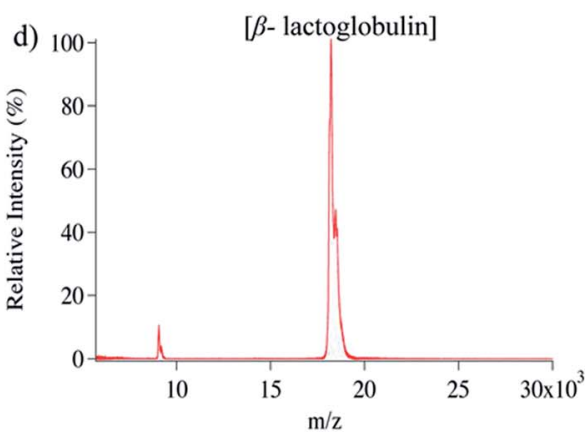

Fig. 3 Optical image of the dried sample $\left(1 \mathrm{mg} \mathrm{mL} \mathrm{m}^{-1} \beta\right.$-lactoglobulin A with $1 \mathrm{M} \mathrm{NaCl}$ ) crystal on a MALDI plate (a) before and (b) after the desalting by the three-well device with an UNPG gel ( $\mathrm{pH} 5-5.27)$ and the obtained mass spectra of $\beta$-lactoglobulin A (c) before and (d) after the desalting. The samples were analyzed by MALDI-MS with sinapinic acid matrix.
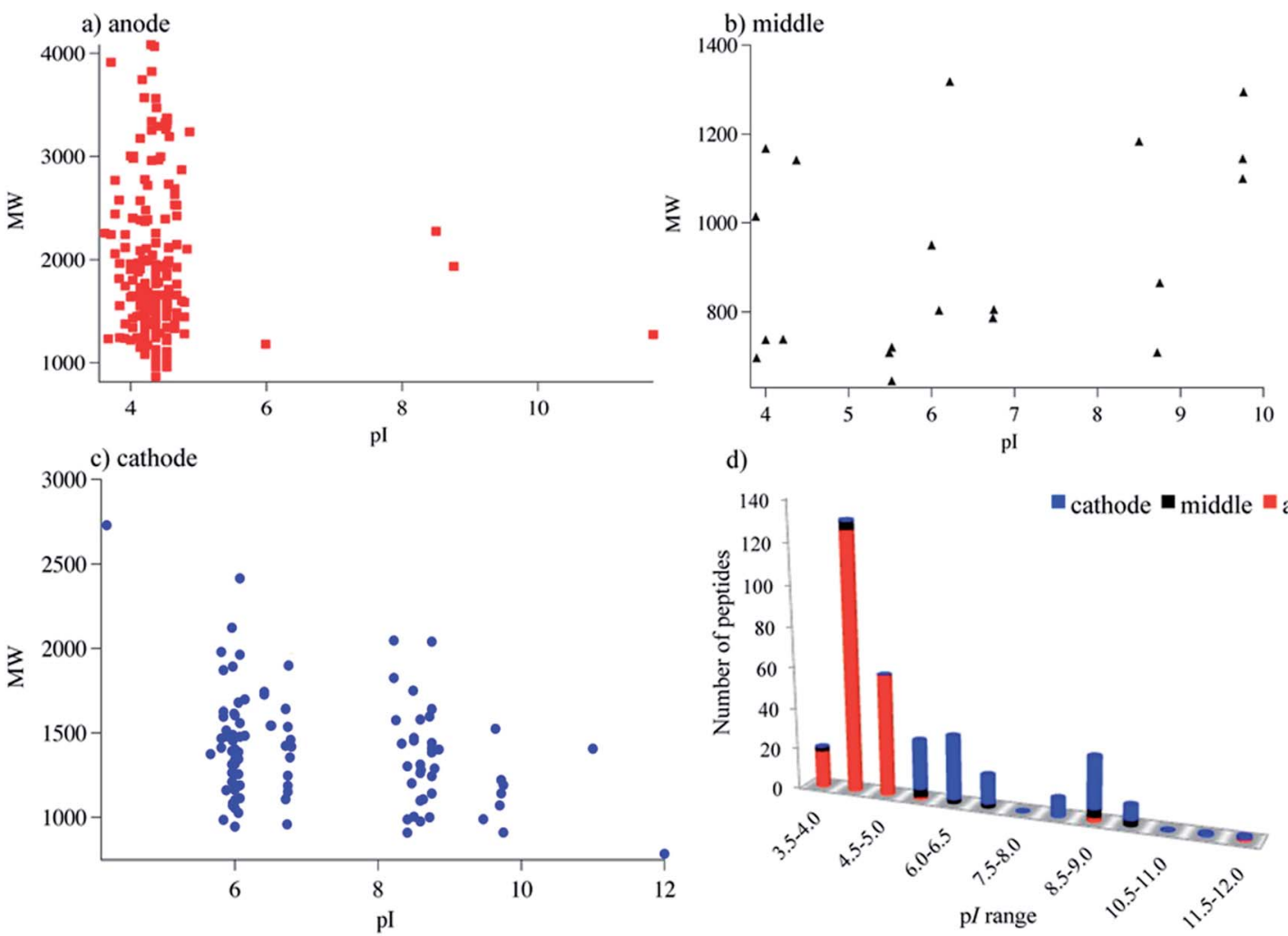

Fig. $4(a-c)$ Isoelectric points plotted as a function of molecular weights for the peptides identified from different wells. (d) Number of identified peptides after OFFGEL fractionation and LC-MS/MS analysis and their isoelectric point distribution. 
cytochrome $\mathrm{C}(\mathrm{pI}=9.6)$ were separated according to the charges developed in the chosen $\mathrm{pH}$ range. Indeed, clear and intense protein bands were visualized and detected in the expected positions (i.e. wells) that corroborates the capabilities of the three-well setup as a powerful tool for protein purification even in the presence of complex matrices. The fraction taken from the middle well with the $\mathrm{pH}$ close to 5.13 shows the highest protein population. Moreover, a well-resolved SDS-PAGE for each well has been obtained compared to the whole E. coli extract. Thus, it confirms that the electrophoretic separation in UNPG gels provides fast and efficient fractionation of proteins and can be applied to the analyses of complex samples.

\subsection{Purification of digested $E$. coli extract followed by LC-MS/ MS analysis}

The purification of peptides derived from the tryptic digest of an E. coli protein extract was also carried out on an UNPG gel. An aliquot of the protein digest $(30 \mu \mathrm{L})$ was loaded in the middle well of the three-well device on a gel strip with a $\mathrm{pH}$ gradient ( $\mathrm{pH}=6-6.27$, mean $\mathrm{pH}=6.15)$. Then, $200 \mu \mathrm{L}$ of water solution was added on top of each well. During the fractionation, the potential increased from 150 to $400 \mathrm{~V}$ in 6 hours with a limiting current of $1 \mathrm{~mA}$. After electrophoresis, the peptide mixture was separated into three fractions, which were present in the liquid phase and can be easily collected for further analysis, for instance, by LC-MS/MS analysis. Each fraction was first lyophilized and re-dissolved in $30 \mu \mathrm{L}$ water, then injected into the LC for LC-MS/MS analysis. The LC-MS/MS data of each fraction were searched against the Escherichia coli database from UniProtKB by the X! Tandem search engine and validated using Trans-Proteomic Pipeline (TPP) tools. The identified peptides from each well by LC-MS/MS are listed in ESI SI-3. $\dagger$ The threshold of probability values from TPP was varied for different LC-MS/MS data while the error rate was constant at $5 \%$.

In Fig. 4, the pI values of the identified peptides from different fractions are compared. From the 1st well, 206 peptides were identified, where only 3 of them had a pI greater than 6. Indeed, the probability scores for these 3 peptides calculated by TPP are quite low (i.e. $0.4233,0.5485,0.5839$ ), and among the lowest ones, indicating that these 3 peptides are highly possible to be false positive identifications. 21 peptides were identified from the fraction of the middle well, where the sample was initially loaded. As shown in Fig. 4, the pI of these 21 peptides is randomly distributed, indicating that a small fraction of the loaded peptides could not migrate into other wells. 113 peptides were identified from the third well by LC-MS/MS. Only one peptide does not match the pI range and actually with a low probability value from TPP as 0.735 . In total 322 peptides with the correct pI were identified by LC-MS/MS after the pre-fractionation step.

All in all, the present results demonstrate that the purification in the three-well device is efficient, and can be easily applied in the analysis of complex samples. Indeed, by optimizing the length of the UNPG-pH strip and its $\mathrm{pH}$, specific and general protein (or peptide) sample fractionations can be obtained.

\section{Concluding remarks}

Protein fractionation by OFFGEL electrophoresis with an immobilized ultra narrow $\mathrm{pH}$ gradient gel in a three-well format has been presented. In comparison to previous OFFGEL electrophoresis reports, ${ }^{\mathbf{1 1}}$ the present work aims at developing a fast and efficient preparative technique for isolation of proteins with a specific $\mathrm{pI}$ from complex biological mixtures in a miniaturized format. The latter opens the possibility to use this preparative technique in combination with a following separation method to provide a powerful tool for proteomics. By tuning the mean $\mathrm{pH}$ of the UNPG gel, a specific target protein can be purified from a mixture of proteins in a short period of time. Fractionation in the three-well device drastically decreases the experimental time: it takes only $4 \mathrm{~h}$ to fractionate a complex mixture such as the $E$. coli extract, while the normal OFFGEL electrophoresis takes up to $8 \mathrm{~h}$. Furthermore, the pH gradient in UNPG gels is very low ( 0.27 units) and close to a constant pH medium. To date, only a few studies by Stoyanov et al. ${ }^{28,29}$ can be found in the literature related to the use of uniform $\mathrm{pH}$ gels for protein fractionation. The proposed approach is low cost, easy to use and can be used in any laboratory.

\section{Acknowledgements}

The authors acknowledge Dr Dmitry Momotenko from the Laboratoire d'Electrochimie Physique et Analytique at the Ecole Polytechnique Fédérale de Lausanne for the help in numerical simulations and Swiss National Science Foundation "Front-end functional microchips for mass-spectrometry (200020_144512/ 1)" for financial support.

\section{References}

1 D. A. Wolters, M. P. Washburn and J. R. Yates, Anal. Chem., 2001, 73, 5683-5690.

2 B. Bogdanov and R. D. Smith, Mass Spectrom. Rev., 2005, 24, 168-200.

3 A. J. Link, J. Eng, D. M. Schieltz, E. Carmack, G. J. Mize, D. R. Morris, B. M. Garvik and J. R. Yates, Nat. Biotechnol., 1999, 17, 676-682.

4 R. Aebersold and M. Mann, Nature, 2003, 422, 198-207.

5 P. H. O'Farrell, J. Biol. Chem., 1975, 250, 4007-4021.

6 J. M. Hille, A. L. Freed and H. Watzig, Electrophoresis, 2001, 22, 4035-4052.

7 A. Pandey and M. Mann, Nature, 2000, 405, 837-846.

8 L. Tonella, C. Hoogland, P. A. Binz, R. D. Appel, D. F. Hochstrasser and J. C. Sanchez, Proteomics, 2001, 1, 409-423.

9 P. G. Righetti, Isoelectric focusing: theory, methodology and applications, Elsevier biomedical press, Amsterdam, 1983.

10 A. Ros, M. Faupel, H. Mees, J. Oostrum, R. Ferrigno, F. Reymond, P. Michel, J. S. Rossier and H. H. Girault, Proteomics, 2002, 2, 151-156.

11 P. E. Michel, F. Reymond, I. L. Arnaud, J. Josserand, H. H. Girault and J. S. Rossier, Electrophoresis, 2003, 24, 3-11. 
12 H.-T. Lam, N. Lion, J. Josserand and H. H. Girault, J. Proteome Res., 2007, 1666-1676.

13 P. Horth, C. A. Miller, T. Preckel and C. Wenz, Mol. Cell. Proteomics, 2006, 5, 1968-1974.

14 L. N. Waller, K. Shores and D. R. Knapp, J. Proteome Res., 2008, 7, 4577-4584.

15 B. J. Cargile and J. L. Stephenson, Anal. Chem., 2004, 76, 267275.

16 J. C. Sanchez, P. Wirth, S. Jaccoud, R. D. Appel, C. Sarto, M. R. Wilkins and D. F. Hochstrasser, Electrophoresis, 1997, 18, 638-641.

17 M. Bier, Electrophoresis, 1998, 19, 1057-1063.

18 K. Hannig, Electrophoresis, 1982, 3, 235-243.

19 P. G. Righetti, E. Wenisch and M. Faupel, J. Chromatogr., 1989, 475, 293-309.

20 M. Cretich, G. Pirri, G. Carrea and M. Chiari, Electrophoresis, 2003, 24, 577-581.
21 N. Lion, J. O. Gellon, H. Jensen and H. H. Girault, J. Chromatogr. A, 2003, 1003, 11-19.

22 I. L. Arnaud, J. Josserand, H. Jensen, N. Lion, C. Roussel and H. H. Girault, Electrophoresis, 2005, 26, 1650-1658.

23 T. Manabe, O. Oda and T. Okuyama, J. Chromatogr., 1982, 241, 361-370.

24 C. Tragas and J. Pawliszyn, Electrophoresis, 2000, 21, 227237.

25 T. Marshall, N. J. Abbott, P. Fox and K. M. Williams, Electrophoresis, 1995, 16, 28-31.

26 E. Tobolkina, F. Cortes-Salazar, D. Momotenko, J. Maillard and H. H. Girault, Electrophoresis, 2012, 33, 3331-3338.

27 H. H. Girault, Analytical and Physical Electrochemistry, EPFL Press, 2004.

28 A. V. Stoyanov, Anal. Biochem., 2009, 386, 116-118.

29 A. V. Stoyanov and P. G. Righetti, Electrophoresis, 1996, 17, 1313-1318. 